\title{
Assessment of the learning styles of students at the Eastern Caribbean Institute of Agriculture and Forestry, Centeno, Trinidad and Tobago and identification of teaching methods used by instructors
}

Cynthia Marie Burskey

West Virginia University

Follow this and additional works at: https://researchrepository.wvu.edu/etd

\section{Recommended Citation}

Burskey, Cynthia Marie, "Assessment of the learning styles of students at the Eastern Caribbean Institute of Agriculture and Forestry, Centeno, Trinidad and Tobago and identification of teaching methods used by instructors" (2004). Graduate Theses, Dissertations, and Problem Reports. 1958.

https://researchrepository.wvu.edu/etd/1958

This Thesis is protected by copyright and/or related rights. It has been brought to you by the The Research Repository @ WVU with permission from the rights-holder(s). You are free to use this Thesis in any way that is permitted by the copyright and related rights legislation that applies to your use. For other uses you must obtain permission from the rights-holder(s) directly, unless additional rights are indicated by a Creative Commons license in the record and/ or on the work itself. This Thesis has been accepted for inclusion in WVU Graduate Theses, Dissertations, and Problem Reports collection by an authorized administrator of The Research Repository @ WVU. For more information, please contact researchrepository@mail.wvu.edu. 
Assessment of the Learning Styles of Students at the Eastern Caribbean Institute of Agriculture and Forestry, Centeno, Trinidad and Tobago and Identification of Teaching Methods used by Instructors

Cynthia Marie Burskey

Thesis submitted to the Davis College of Agriculture, Forestry and Consumer Sciences at West Virginia University in partial fulfillment of the requirements for the degree of

Master of Science

in

Agriculture Education

Harry N. Boone, Jr., Ph.D., Chair Stacy A. Gartin, Ph.D. Jean M. Woloshuk, Ed.D. Deborah A. Boone, Ph.D.

Division of Resource Management

Morgantown, West Virginia 2004

Keywords: Learning Styles, Teaching Methods, Personality Models 


\begin{abstract}
Assessment of the Learning Styles of Students at the Eastern Caribbean Institute of Agriculture and Forestry, Centeno, Trinidad and Tobago and Identification of Teaching Methods used by Instructors

Cynthia Marie Burskey

An issue in higher education is to create a learning environment that is both positive and effective. With teaching methods that take into account all the learning styles within the classroom, a teacher can make the atmosphere of the classroom more conducive to learning. This study sought to determine if the teachers at the Eastern Caribbean Institute of Agriculture and Forestry, Centeno, Trinidad and Tobago (ECIAF) were using instructional methods that facilitated learning in their students. A two-phase study was utilized. Phase I used a descriptive survey to determine the learning styles of 36 first-year students at ECIAF. Phase II used qualitative research methods to determine the teaching styles used by teachers at ECIAF. The teachers at ECIAF were found to teach to the majority of the learning styles of the students at ECIAF.
\end{abstract}




\section{DEDICATION}

This thesis is dedicated to my parents who throughout my education have been my support system. I love you. 


\section{ACKNOWLEDGEMENTS}

I would like to express my sincere gratitude to my graduate advisor, Dr. Harry N. Boone, for his unwavering encouragement. When I was confused, frustrated, or just tired he was always there to keep me on task and willing to help in any way he could. Thank you Dr. Boone for making this truly a learning experience.

A special thanks to the members of my graduate committee including: Dr. Jean M. Woloshuk, Dr. Stacy A. Gartin, and Dr. Deborah A. Boone. Without their help I would not have been able to attain my graduate degree.

To Dr. Layle Lawrence, who helped with all the traveling plans that enabled me to go to Trinidad and Tobago. Thank you for the inspiration and time you put into making my thesis project work.

To Mr. Carlton Sambury, ECIAF staff, and ECIAF students. Thank you for your hospitality and the enthusiasm shown to me during my stay.

A special thanks goes to the staff and residents (especially the $2^{\text {nd }}$ floor) of Lyon Tower. Your encouragement and help was truly appreciated.

Last but not least I would like to express my thanks to Daniel Lima. His willingness to listen, give support and provide help has been invaluable. You are truly my rock! 


\section{TABLE OF CONTENTS}

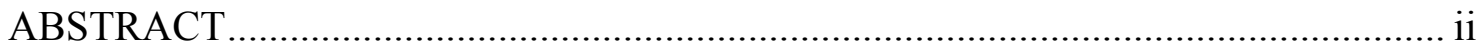

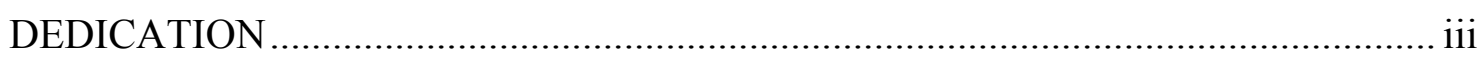

ACKNOWLEDGEMENTS ........................................................................... iv

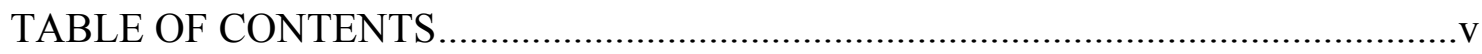

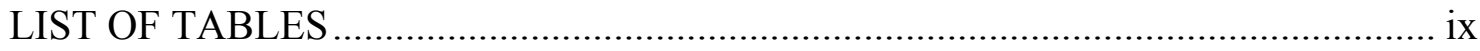

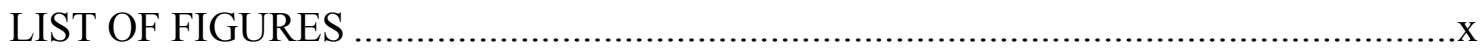

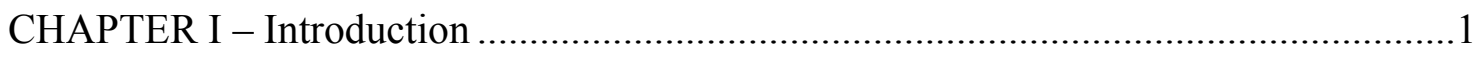

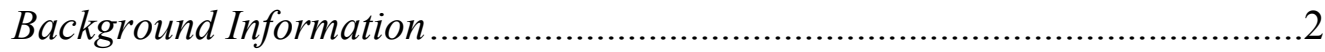

Statement of Problem ................................................................................ 5

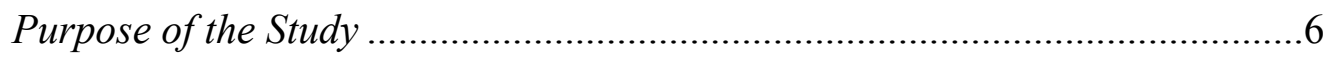

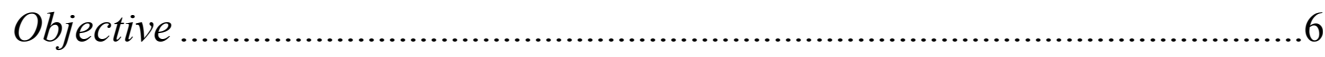

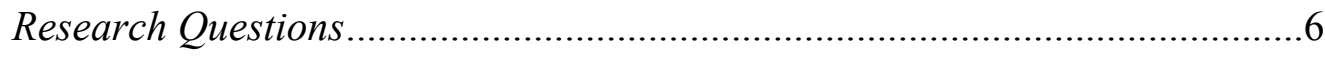

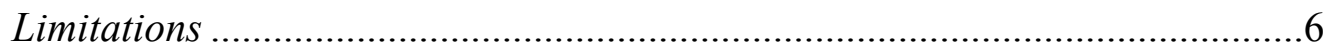

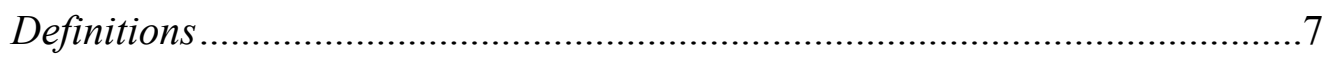

CHAPTER II - Review of Literature .........................................................

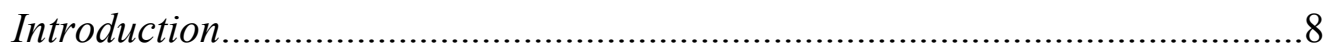

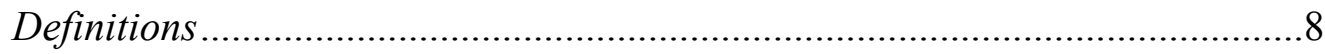

Applications of Learning Style ............................................................ 10

A Personal Approach .................................................................. 10

A Holistic Approach ..................................................................... 11

Teaching to all Types ................................................................ 11

Teaching Style versus Learning Style ........................................................ 12 
Types of Learning Style Assessments .................................................... 13

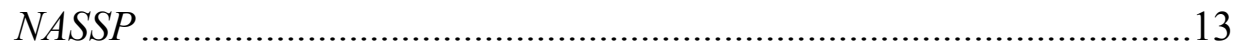

Dunn and Dunn Model................................................................13

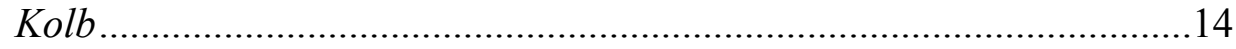

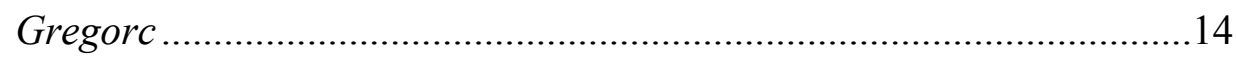

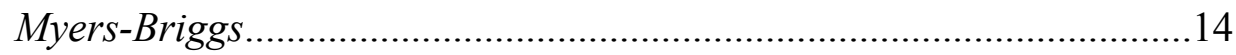

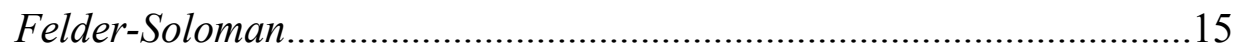

Implications for Higher Education ...................................................... 16

Assumptions about Postsecondary Learners ............................................17

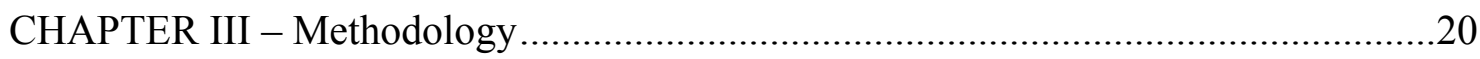

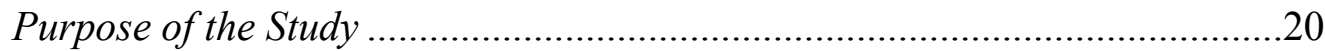

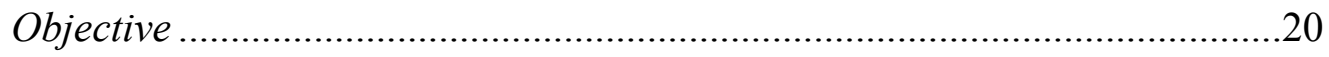

Research Questions......................................................................20

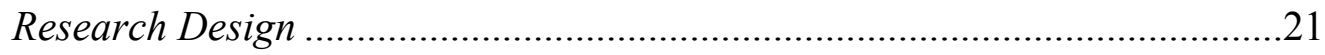

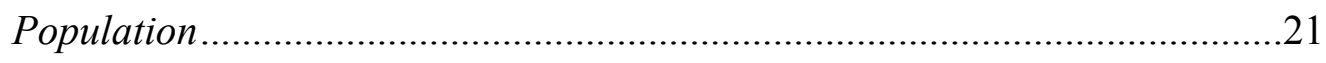

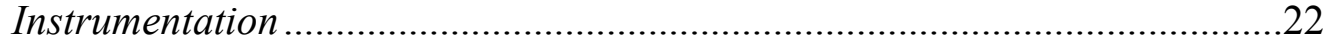

Data Collection Procedures ....................................................................23

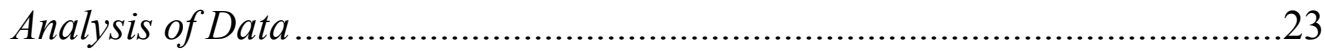

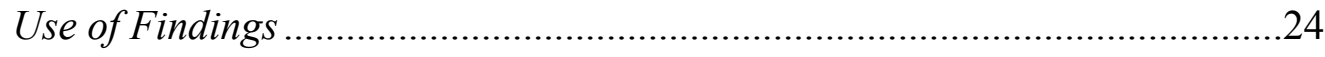

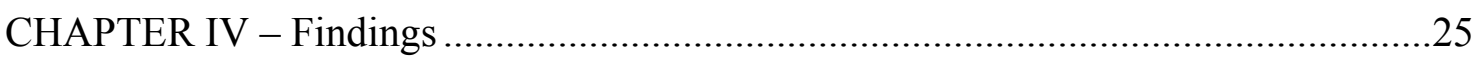

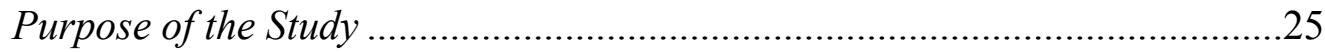

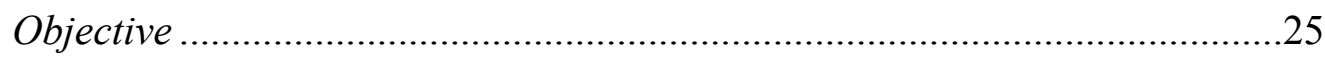

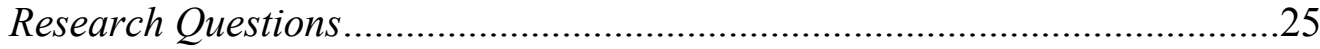




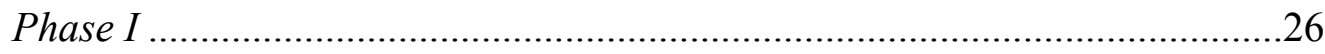

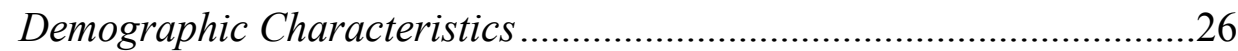

Distribution of Learning Style Frequency ............................................27

Distribution of Learning Style Frequency by Gender - Male ..................27

Distribution of Learning Style Frequency by Gender - Female.............29

Distribution of Learning Style by College - Agriculture .........................29

Distribution of Learning Style Frequency by College - Forestry ...........30

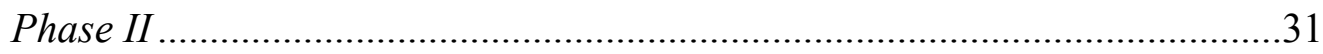

Distribution of Teaching Style Frequency .............................................31

CHAPTER V - Conclusions, Implications, and Recommendations ...............................34

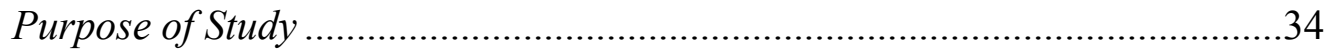

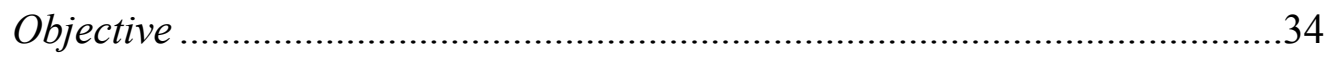

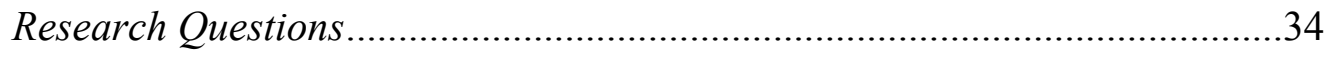

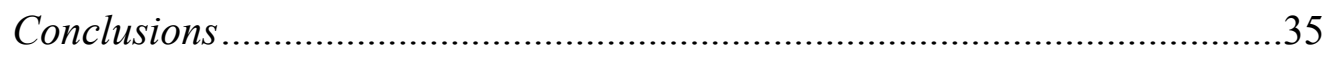

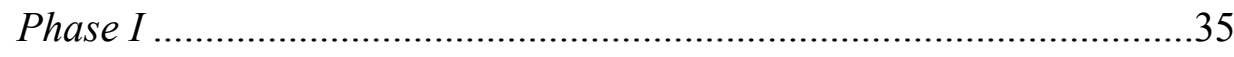

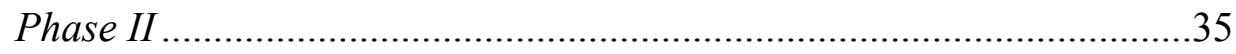

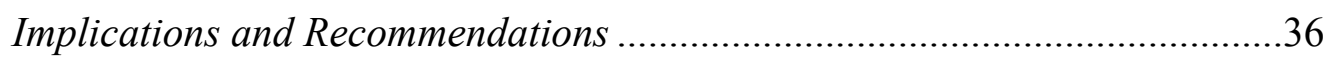

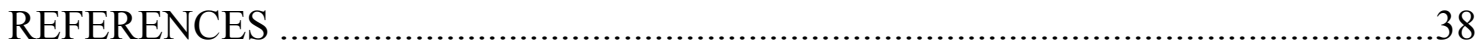

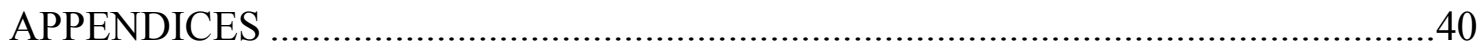

APPENDIX A: Index of Learning Styles by Felder \& Soloman (1991).........41

APPENDIX B: ILS Scoring Sheet.................................................................46

APPENDIX C: Teaching Style Checklist........................................................48

APPENDIX D: Letter of Introduction \& Survey Directions .............................50 
APPENDIX E: Research Funding Proposal ... 


\section{LIST OF TABLES}

Table

Page

1. Distribution of Learning Style Frequency ..................................................28

2. Distribution of Learning Style Frequency by Gender - Male ...........................28

3. Distribution of Learning Style Frequency by Gender - Female.......................29

4. Distribution of Learning Style by College - Agriculture ...................................30

5. Distribution of Learning Style by College - Forestry .....................................31

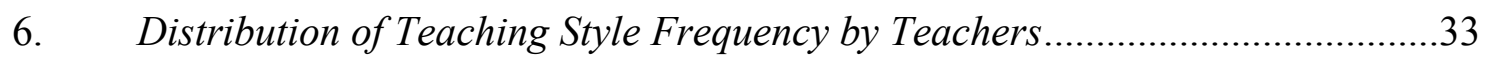




\section{LIST OF FIGURES}

Figure

Page

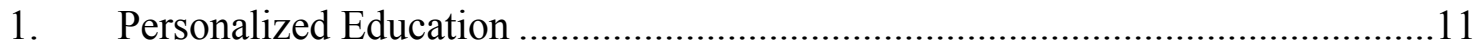

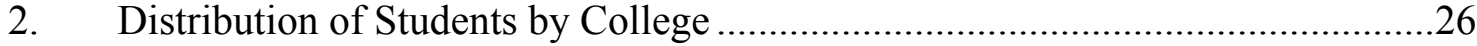

3. Distribution of Respondents by Gender ....................................................26 


\section{CHAPTER I}

Introduction

Walls (1999) defined learning in three ways. The first is the behavior definition, which says "learning is the change in behavior after experience or practice" (p. 6). The second definition is the process definition, which says "learning is a process that is shown by a change in behavior after experience or practice" (p. 7). The last definition is the neural definition, which states "learning is a change in the neural association structure of the brain after experience or practice" (p. 8). As a teacher, one should understand how learning occurs and be able to use this information to "facilitate the learning process."

Walls (1999) stated, that effective teaching combines four things: outcomes, clarity, engagement, and enthusiasm. Teachers should be able to identify what the outcomes of learning should be and be clear in their teaching methods. A good teacher gets all the students involved and also shows enthusiasm while teaching. Engagement is very important in teaching. If a teacher incorporates engagement activities within his or her classroom then the student will be more apt to learn. Piaget (as cited in Walls, 1999) said that when teachers understand how a learner learns and thinks, then that enables the teacher to present information so the student will also learn.

According to Serasin (1999), a teacher must realize that each student learns differently. This concept is called a learning style. A learning style is the preference of an individual to perceive and process information in a particular way or a combination of ways (Serasin, 1999).

Sims and Sims (1995) indicated that effective learning occurs when instructors recognize the presence of these diverse learning styles and maximize the climate or 
conditions for learning in and out of the classroom through the deliberate use of instructional design principles that take account of learning differences and increase the possibilities of success for all learners.

Serasin (1999) stated that, instructors at the postsecondary level have a certain responsibility for understanding and applying learning styles research because teaching strategies at this level have traditionally been centered around the lecture. Therefore, students with learning styles that are not very compatible with the traditional lecture approach will be at a disadvantage in a learning situation such as this and may not succeed unless their instructors can accommodate their styles.

\section{Background Information}

In October of 2000 the College of Science, Technology and Applied Arts of Trinidad and Tobago (COSTAAT) was established by Act 77, 2000 of Parliament. Its stated mission is to be the;

premier national institution in providing high-quality, affordable and accessible educational programs and services; satisfying the needs of business, industry and the wider community; and creating a college community that promotes personal development, professional competence and social responsibility. This mission derives from the institution's vision to be a dynamic, innovative, world-class and student-centered multicampus college, promoting excellence in teaching and learning, serving diverse communities, and producing lifelong learners who can compete globally (Chapman, et al., 2003 p. 3). 
The Eastern Caribbean Institute of Agriculture and Forestry (ECIAF) became a part of the COSTAAT institution in 2000. To become a premier institute, COSTAATT identified needs to be fulfilled by the new community college system in its proposal to the Caribbean Development Bank. The needs were:

1. Provide workforce training in response to labor market demands;

2. Undertake retraining and upgrading skills of the existing labor force in consultation with business, industry and state agencies;

3. Broaden access to tertiary education by providing pathways for previously underserved groups to access higher education through the introduction of a comprehensive transitional studies program, credit for experiential learning, credit for workplace training, and selective use of challenge examinations for course exemptions;

4. Offer transfer degrees which articulate with baccalaureate and post-graduate programs and, in so doing, contribute to the development of a seamless, higher education system in Trinidad and Tobago;

5. Deliver customized training and community-based education programs;

6. Increase enrollment and widen access through the introduction of new technologies and instructional delivery modes such as distance education;

7. Institute a robust internal quality assurance system in order to significantly improve the quality and relevance of current tertiary provision and ensure that all programs and services meet the highest regional and international standards; and 
8. Ensure greater efficiencies in the allocation of financial and human resources in the national public tertiary sector.

During the week of March 2-7, 2002, West Virginia University and COSTAATT held a series of discussions in order to start a partnership between the two institutions. As a result, four desired outcomes of the collaboration were identified:

1. Conduct a critical review of current program offerings in an effort to determine ways to a) broaden access, b) increase enrollment, and c) maximize the use of the physical plants and equipment of the programs involved;

2. Design and offer recommendations for the implementation of post-graduate training for COSTAAT faculty;

3. Design and offer recommendations for the implementation of a comprehensive professional development distance education plan; and

4. Recommend areas in which the establishment of exchange and cooperative programs might be beneficial for students and faculty of the two institutions.

Every year, ECIAF admits 25 agricultural students and 25 forestry students, consequently there are approximately 100 students on campus. The school has approximately 13 faculty members. The student ages range from 17 and up with the majority between 23-35 years of age. The majority of the students who attend ECIAF are looking for a way to improve their success in their profession so that they can easily move up the management and/or salary ladder. Most of the students take a leave of absence from their respected profession to attend school.

A team of consultants from West Virginia University visited the campuses of COSTAAT in the Republic of Trinidad and Tobago during January 2003. They met with 
faculty and staff in order to determine the extent to which collaboration between COSTAAT and WVU might be feasible and mutually beneficial to the two institutions (Chapman, et al., 2003 p. 3).

Chapman et al., (2003) stated that, upon the assessment of the current programs the team for ECIAF found no data that would be necessary to assess the quality of current programs in COSTAAT. The team was not given any information that documented any type of objective self-assessment, nor did the team see any indication that there had been an external validation of the effectiveness of these existing programs. It was also reported that some faculty members did not discharge their duties and responsibilities as teachers, and that others were derelict in their duties to the extent that they did not respond in a timely manner to requests from the administration for documents related to the programs with which they were associated.

Based on this data a number of areas for improvement were identified. A major issue that needed attention was the quality of the classes. Economics, communication skills and mathematics should be integrated throughout the curriculum and the curriculum should reflect current and future needs of the students (Chapman et al., 2003). Statement of Problem

Research has shown that maximum academic achievement is accomplished when teaching techniques take into consideration the learning styles of the students in the class. West Virginia University has been retained to provide technical assistance to ECIAF to improve the instructional program at the school. The first step in improving the instructional program was to determine the learning styles of the students as well as the instructional techniques the faculty used to facilitate the various learning styles. 


\section{Purpose of Study}

The purpose was to determine the learning styles of first-year students at ECIAF and to determine the teaching strategies faculty used to match instruction with learning styles.

\section{Objective}

The objective of the study was to determine if the teachers at ECIAF were using instructional methods that facilitated learning in their students. The current first-year students at ECIAF were assessed and taught about their learning styles so that they could understand how they learn. In addition, instructors at ECIAF were observed to determine the degree to which they utilized teaching methods that took into consideration the learning styles of their students.

Research Questions

Specific objectives are reflective in the following questions:

1. What were the predominate learning styles of the first-year students at the Institute?

2. What instructional methods did instructors at the Institute use?

3. To what extent did the learning styles of the students and teaching methods of instructors compliment each other?

\section{Limitations}

This study was limited to the teachers who were teaching and the students who were attending ECIAF during the short trimester June 2003. 


\section{Definitions}

1. Learning Styles - certain specified pattern of behavior and/ or performance according to which the individual approaches a learning experience, a way in which the individual takes in new information and develops new skills, and the process by which the individual retains new information or new skills.

2. Pedagogy - The science or profession of teaching. 


\section{CHAPTER II}

Review of Literature

\section{Introduction}

An issue in higher education is the use of learning style research to create more positive, effective learning environments for all students. College students no longer have uniform academic backgrounds due to the college preparatory programs, because high schools provide a more diversified curriculum allowing for more elective courses (Griggs $\&$ Price, 1985). With the increased social and cultural diversity in college classrooms, researchers have begun to raise questions about the mediating influence of culture in learning style differences (Swanson, 1995).

Sheal (1989) believes that the most important responsibility is to find out how students minds work. In understanding how students' minds work, instructors can begin to understand the importance of knowing about learning styles and how they relate to the success of their students.

According to Serasin (1999), all teachers should keep current with methodologies and strategies because of the growing research in this area. Instructors at postsecondary levels are usually specialists in their area but know very little about the pedagogical and andragogical research. "It is critical that postsecondary instructors, whatever their field and setting, appreciate the complexity of the learning process and understand about learning styles and how they relate to the learning success" (Serasin, 1999, p. 1).

\section{Definitions}

What is a learning style? The concept of learning styles has not always been a common word in the profession of teaching. According to Swanson (1995) in the earlier days the 
term was actually cognitive style. Cognitive style is defined in several ways: 1) a person's typical mode of perceiving, thinking, remembering, and problem-solving; 2) cognitive characteristic modes of functioning that are revealed through one's perceptual and intellectual activities in a highly consistent and pervasive way; 3) a superordinate construct involved in many cognitive operations that accounts for individual differences in a variety of cognitive, perceptual, and personality variables; and 4) intrinsic information processing patterns that represent a person's typical modes of perceiving, remembering, thinking, and problem solving (Claxton \& Murrell, 1987; Griggs, 1991; and Green, 1985).

According to Kirby (1979) the term "learning style" came into use when researchers began looking for ways to combine course presentation and materials to match the needs of each learner. Cognitive style and learning style have often been used together in literature and research but they are not the same. Learning style is a broader term that includes cognitive style (Keefe, 1987). According to Keefe (1987) there are actually three dimensions of learning styles: 1) cognitive, 2) affective, and 3) physiological. The reason that cognitive style and learning style are sometimes confused is because the cognitive dimension is very widely researched unlike the affective and physiological dimensions.

The affective dimension of learning style has to do with attention, emotion, and the valuing part of a person's personality. Physiological styles are biologically-based modes of response that are founded on sex-related differences, personal nutrition and health, and accustomed reaction to the physical environment. 


\section{Applications of Learning Style}

A Personal Approach. No educational program can be successful without attention to the personal learning needs of individual students. Keefe (1987) describes this method of personalized education as a "systematic effort on the part of a school to take into account individual student characteristics and effective instructional practices in organizing the learning environment” (p. 40). This program starts by identifying the learner's needs and then adapting the instructional needs around the learner to create an optimal learning environment. Figure 1 demonstrates how this program works. There are four major steps (Keefe, 1987):

1) Diagnosis - Identify learning style and learning history.

2) Prescription - Teachers identify specific goals and objectives by advisement of students.

3) Adaptive instruction - Teachers structure the learning environment, train students in study and thinking skills and manage time use.

4) Evaluation - Student assessment and program evaluation are needed to determine if students are improving. (see Figure 1) 


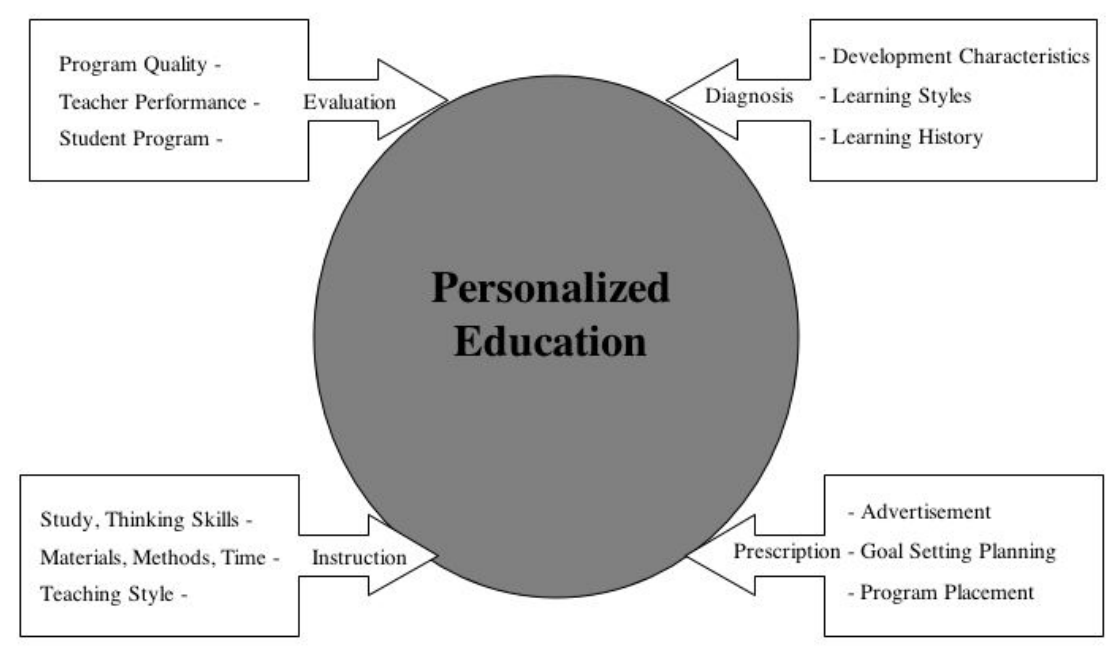

Figure 1. Personalized Education (Keefe, 1987, p. 40)

A Holistic Approach. Another approach to using learning styles within the classroom is to use a holistic approach. According to Serasin (1999) a holistic approach does not mean that an instructor has to teach 20 different ways. "It is important to make accommodations within individual lessons for the differences among the students in the group, to allow every student the opportunity to learn as he or she learns best"(Serasin, 1999, p. 7). This teaching method allows the teacher to combine teaching techniques in order to address the different learning styles. Extra effort is needed by the instructor to prepare a variety of strategies and activities but Serasin (1999) states that, "the results are often worth the extra effort"(p. 8).

Teaching to all Types. According to Felder (1996) there is a strategy that can ensure that instructors will present information that appeals to a range of learning styles. This is geared towards engineering students but may be helpful to other instructors. The nine types include: 
1) Teach theoretical material by first presenting phenomena and problems that relate to the theory.

2) Balance conceptual information with concrete information.

3) Make extensive use of sketches, plots, and physical demonstrations in addition to oral and written explanations in lectures and readings.

4) Illustrate an abstract concept; use at least one numerical example to supplement the usual algebraic example.

5) Use physical analogies and demonstrations to illustrate the magnitudes of calculated quantities.

6) Occasionally give some experimental observations before presenting the general principle, and have the students (work in groups) see how far they can get toward inferring the latter.

7) Provide class time for students to think about the material being presented and for "Active" student participation.

8) Encourage and mandate cooperation on homework.

9) Demonstrate the logical flow of individual course topics but also point out connections between the current material and other relevant material in the same course, in other courses in the same discipline, in other disciplines, and in everyday experience.

\section{Teaching Style versus Learning Style}

According to Haring (1985) each of us are learners, which have different teaching styles. Our learning style, will affect our teaching style (Cornett, 1983). Instructors naturally tend to teach in ways that are consistent with how they learn. In conclusion, 
"teachers tend to prefer to teach the way they prefer to learn unless a conscious effort is made to do otherwise" (Haring, 1985, p. 7). Haring (1985) stated that assessing a teachers learning style might enhance their understanding of learning styles. The more a teacher knows about teaching and learning styles the more they can modify their teaching approach to help each student.

Should students be matched up with a teacher who has the same learning/teaching style? While this may seem to be an optimal situation it is not. According to Haring (1985) the desirable option would be to encourage student and teacher to flex their styles by not matching student and teacher styles. "The student flexing their styles will create a greater ability to learn under varying conditions and in different contexts" (Haring, 1985, p. 8).

Types of Learning Style Assessments

Today we live in the age of the Internet. If you simply go online and type in "learning style" you get hundreds of hits for many different types of assessments. There are several that seem to have been forefathers for the ones available on the Internet today.

NASSP. This instrument was written in conjunction with Dr. James Keefe and the National Learning Styles Task Force. This learning style model encompasses physiological/environmental, cognitive, and affective domains, as well as an information processing perspective. The assessment is a 42 page, 126-question test that is intended for secondary students.

Dunn and Dunn Model. Kenneth and Rita Dunn were of the earliest research teams in the field of learning styles (Debello, 1989). This model is considered multidimensional. It includes five stimuli groups: environmental, emotional, sociological, 
physiological, and psychological areas. It also contains 21 subcategories that are referred to as elements. There are many different forms of the instrument. The Learning Style Inventory is comprised of 100 items and requires approximately 30 minutes to administer. The Productivity Environmental Preference Survey (Dunn, Dunn, \& Price, 1977) is a version intended for adults and may have applications outside of the school setting.

Kolb. This learning model is based on an experiential learning model. This model is a nine-item assessment with four sub-items to be ranked by adults. Its primary use includes adult organizational systems and management training. According to Debello (1989) there are different variations of the model being used today.

Gregorc. This model's basis is that style consists of distinctive observable behaviors, which provide clues to how people think and how they can relate this to the world around them (Debello, 1989). Abstract, concrete, random, and sequential are the different types assessed in this instrument. Debello (1989) states that Gregorc emphasizes the matching of instructional materials and methods to accommodate the different learning styles in the classroom. He also emphasizes that instructors should teach in a variety of different styles so that a student can learn how to learn in different ways.

Myers-Briggs. This inventory is based on psychological types derived from Carl Jung's theory. The types are: extraverts/introverts, sensors/intuitors, thinkers/feelers, and judgers/perceivers. The type preferences can be combined to form 16 different learning style types. For example, a student may be an ISFJ or in other words an introvert, sensor, feeler and judger. 
Felder-Soloman. In this study, The Index of Learning Styles (ILS)(1991) was used to assess the population. This model has four dimensions and is available online. According to Felder (1993) the dimensions are described as follows:

1. Processing (Active/Reflective)

- “Active" learners tend to learn while doing something active, they try things out and like to work in groups.

- "Reflective" learners do more processing introspectively, which means they think things through before trying them out. Reflective learners prefer to work alone or in pairs.

2. Perception (Sensing/Intuitive)

- Sensors tend to like facts and observations; they like to solve problems using well-established procedures. Sensors may also be slow but enjoy complicated or unexpected twists in their work.

- Intuitors prefer concepts and interpretations; they also like variety in their work. Intuitors don't mind complexity, and get bored with too much detail and repetition, which may lead to carelessness in their work.

3. Input (Visual/Verbal)

- Visual learners get more information from visual images and learn better by actually seeing pictures, diagrams, graphs, schematics, and demonstrations

- Verbal learners get more information from written or spoken words 


\section{Understanding (Sequential/Global)}

- Sequential learners absorb information and acquire understanding of material in small-connected chunks. Sequential learners can solve problems with incomplete understanding of the material and their solutions are generally orderly and easy to follow.

- Global learners can only master details of a subject by being presented material that relates to the students prior knowledge and experience. Unfortunately, many students who learn this way do not always get the best grades in school because teachers do not routinely provide broad perspectives.

\section{Implications for Higher Education}

Should learning styles be incorporated into the instruction methods used in secondary and postsecondary institutions? According to Matthew (1995) learning style is extremely important to consider in improving curricula and instruction in secondary and postsecondary schools. Information about learning style assists faculty to become more sensitive to the variegated experiences and motives students bring to the classroom. Matthews (1995) stated that assessing students lets instructors see what kind of learning styles they are dealing with and structure the lessons around the learning style by using appropriate teaching methods.

According to Claxton and Murrell (1987) learning style has not significantly affected educational practices in higher education. There are two reasons why: 1) learning and teaching are not a major concern because there is too much emphasis on 
research in traditional disciplines, and 2) the issues surrounding the concept are poorly framed and the characteristics of learners with it are difficult to assess.

Assumptions about Postsecondary Learners

Understanding postsecondary students learning styles is very important as instructors so that curriculum can be developed around the students. Knowles et al., (1984) have made some general assumptions about postsecondary students:

1) Postsecondary students are motivated to learn because they have had different experiences that they can reference for new information.

2) Postsecondary students have a work-centered attitude. They need to have curricula designed around real life information.

3) Postsecondary students need to learn experientially.

4) Lessons should encourage students to make their own decisions and to also encourage students to take ownership of learning.

5) Postsecondary instructors need to take into consideration that adult learners have adapted to learning by the use of a variety of different teaching methods. Ramirez (1982) suggested a framework that both focuses on the individuals learning style. He also supports using an instructional method that increases a students learning ability by using ways that they have not previously experienced.

Claxton and Murrell (1987) made four recommendations for institutions of higher education to improve the teaching and learning process.

1) Conduct professional development activities on the use of learning style in improving teaching and student development. This recommendation suggests that institutions make it available for their instructors to attend workshops, and 
seminars to better understand the importance of using learning styles in the classroom.

2) Promote classroom research and make data about learning style an important part of it. Research should not only include the specialized disciplines but research should also be conducted in teaching-learning processes. Claxton and Murrell (1987) explain "The collection of this data can also contribute to a continuing dialogue among faculty and administrators as they learn from each other about teaching and learning" (p. 8).

3) Establish curricular experiences that focus on helping students learn how to learn. Claxton and Murrell (1987) suggest that there should be orientation activities or a course that can help students better understand how they learn. The use of learning style inventories can make students aware of their own preferences and strengths. Attention should also be given to help students develop strategies for succeeding in courses taught that do not match with their own learning style.

4) In hiring new faculty members, take into account candidates' understanding of teaching and learning practices. In this final recommendation a realization exists that faculty preparation should include other areas of knowledge as well. According to Swanson (1995), "a background in student development, learning theory, and ways to creatively combine content and process are all important perquisites for effective teaching" (p. 17).

It is important for postsecondary students to understand how they learn and to be able to use this information to help them study and understand information presented in class. On the other hand, it is critical for postsecondary instructors to understand the 
learning style concept and apply what they have discovered into their classrooms. It is no longer acceptable to lecture to students. It is about making classrooms exciting and to make it open for everyone to learn. According to Serasin (1999), professional development in this subject should be understanding research and include active participation in planning for implementation of learning styles research. Active planning includes curriculum design as well as lesson planning. The ultimate goal one should always think about is how to promote the success of each student. 


\section{CHAPTER III}

\section{Methodology}

\section{Purpose of the Study}

The purpose of the study was to determine the learning styles of first-year students at Eastern Caribbean Institute of Agriculture and Forestry (ECIAF) and to determine the teaching strategies faculty used to match instruction with student learning styles.

\section{Objective}

The objective of the study was to determine if the teachers at ECIAF were using instructional methods that facilitated learning in their students. The current first-year students at ECIAF were assessed and taught about their learning styles so that they could understand how they learn. In addition, instructors at ECIAF were observed to determine the degree to which they utilized teaching methods that took into consideration the learning styles of their students.

\section{Research Questions}

The following research questions were used to guide the research:

1. What are the predominate learning styles of the first-year students at the Institute?

2. What instructional methods do instructors utilize at the Institute?

3. To what extent do learning styles of students and teaching methods of instructors coincide? 


\section{Research Design}

A descriptive research design was used for phase I the study in. A directly administered survey data collection method was used because the response rate would be close to 100 percent. This allowed the researcher to get results quickly and inexpensively and it allowed the researcher to organize, summarize, and describe the observations (Ary, Jacobs, \& Razavieh, 2002).

Phase II was a qualitative case study. According to, Ary et al., (2002) case studies are used to examine an individual or unit in depth. This method allowed the investigator to discover all variables that were important in the history or development of the subject. The emphasis was on understanding why a person acts the way he or she does and also placed emphasis on the behavior changes as the environment changes. A case study also gave the researcher an opportunity to explain the present status of the individual or unit (Ary et al., 2002).

\section{Population}

The target population for phase I of this study consisted of a census of the 40 firstyear students at ECIAF during the summer of 2003. The school has two vocations: forestry and agriculture. The accessible population was 36 of the 40 students. Four students could not be assessed due to class time constraints of the forestry students. The target population for phase II consisted of thirteen instructors at ECIAF who were employed at ECIAF during the summer of 2003. Due to the shortened summer trimester, data were collected from only five instructors. 


\section{Instrumentation}

In phase I each student's learning style was assessed using The Index of Learning Styles (ILS) model created in 1991 by Felder and Soloman. Their model has four dimensions Processing (Active/Reflective), Perception (Sensing/Intuitive), Input (Visual/Verbal), and Understanding (Sequential/Global). The ILS was reviewed by a panel of experts consisting of faculty members of the Davis College of Agriculture, Forestry, and Consumer Sciences to establish its content validity for the target population.

In a recent study, Zywno (2003) of Ryerson University collected ILS responses for several hundred engineering students and assessed test-retest reliability, internal consistency reliability, and several quantities related to the independence and construct validity of the four instrument scales. She concluded that the ILS meets criteria of acceptability for instruments of its type. In another study, Livesay (as cited in Zywno 2003 ) in a study of 255 engineering students at Tulane University, New Orleans, found the instrument's reliability to range between an alpha level of 0.54 to 0.72 . The study also found relatively high test-retest reliability in repeated measurements over time, and concluded that the ILS was an appropriate and statistically appropriate tool for characterizing learning preferences (Zywno, 2003).

In phase II, the instructors were assessed by an inventory designed by the researcher. The checklist includes the eight dimensions of the learning style assessment, The Index of Learning Styles. The instrument was presented to the researchers committee to evaluate the credibility and transferability. The Index of Learning Styles checklist, was determined to be relevant and meaningful to the study and credible and transferable. The 
instrument assessed the relevant aspects of the conceptual domain that it was measuring and it was concluded by the committee that the ILS had credibility. Since the principle researcher was the only one collecting the data, and interrater reliability was controlled.

\section{Data Collection Procedures}

In phase I two sessions were held to facilitate a response rate of $100 \%$. In the first session 32 agriculture students were assessed. In the second session the researcher assessed five forestry students. The students were presented a short PowerPoint presentation on the value of understanding how they learn. They were then given the ILS to complete. The students scored their own test after receiving specific instructions. The researcher then shared a short presentation on each learning style and explained how each type could improve his or her own study habits. The researcher also expressed that by learning how each person learns can help improve his/her understanding of educational information.

In phase II the teaching methods used by instructors were observed while the researcher shadowed the agriculture and forestry students through their daily schedule. Methodologies were determined by comparing the teaching methods that were being used in class to the learning styles highlighted in the ILS. The teaching methods were recorded on a checklist designed by the researcher.

Analysis of Data

For phase I, data were entered in an Excel spreadsheet then verified by the researcher. The data were then transferred into SPSS version 11 for data analysis. Appropriate descriptive statistics were used based on the nominal scale of measurement. 
For phase II, the data was organized by categories of the different learning styles and how many times each style was used. The information was then put into strategy codes. According to Ary et al., (2002),

Developing coding strategies enables the researcher to physically separate material bearing on a given topic from other material and is a crucial step in organizing the data. Methods coding include the research procedures, methods, problems, and reflections to which the researcher refers during the inquiry" (p. 466).

This method coding enabled the researcher to tell which teaching methods were used the most in the classroom. The data was summarized by examining all the entries with the same coding and recognizing the relationships among the categories. Then the data was interpreted by examining all categories and determining which teaching style was used the most.

\section{Use of Findings}

The results of the test will be given to the instructors of ECIAF so they can study the findings. The instructors were able to see the make-up of learning styles with their first-year students. By employing the statistics the instructors will be able to develop classes using teaching methods that will accommodate the diversity of learning styles within the classroom. 


\section{CHAPTER IV}

\section{Findings}

\section{Purpose of the Study}

The purpose of the study was to determine the learning styles of first-year students at Eastern Caribbean Institute of Agriculture and Forestry (ECIAF) and to determine the teaching strategies faculty used to match instruction with student learning styles.

\section{Objective}

The objective of the study was to determine if the teachers at ECIAF were using instructional methods that facilitated learning in their students. The current first-year students at ECIAF were assessed and taught about their learning styles so that they could understand how they learn. In addition, instructors at ECIAF were observed to determine the degree to which they utilized teaching methods that took into consideration the learning styles of their students.

\section{Research Questions}

The following research questions were used to guide the research:

1.What are the predominate learning styles of the first-year students at the Institute?

2.What instructional methods do instructors utilize at the Institute?

3.To what extent do learning styles of students and teaching methods of instructors coincide? 


\section{Phase I}

The 36 respondents to the learning style questionnaire represented the Eastern Caribbean Institute of Agriculture and Forestry, Centeno, Trinidad and Tobago (ECIAF). The respondents included both forestry and agriculture students within ECIAF. There were 31 agriculture students $(86.1 \%)$ and 5 forestry students (13.9\%) (see Figure 2).

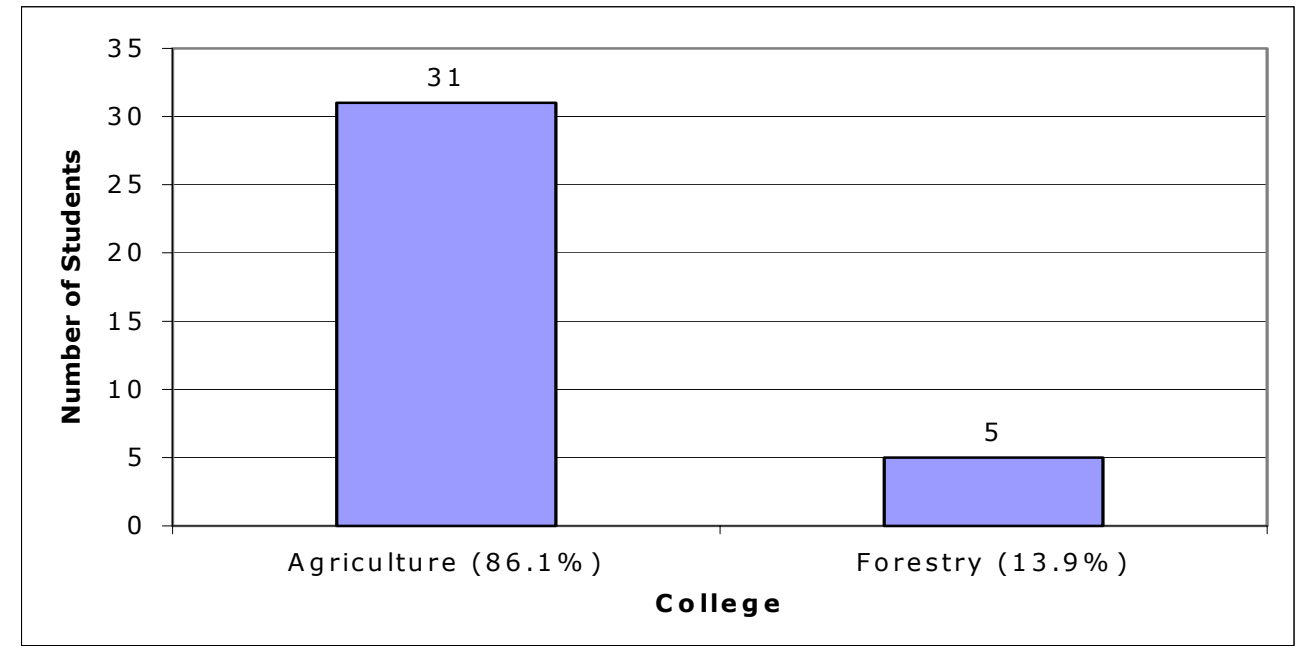

Figure 2. Distribution of Students by College

Demographic Characteristics. Participants were asked to identify their gender.

Twenty-one students were male (58.3\%), while 15 were female (41.7\%) (see Figure 3).

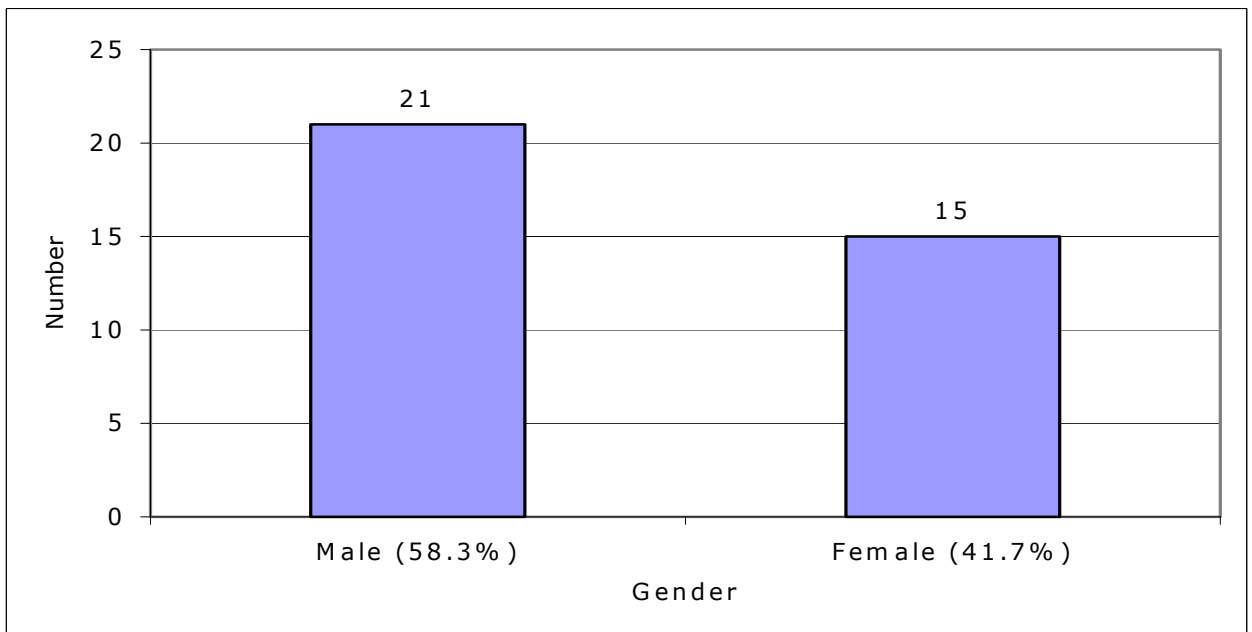

Figure 3. Distribution of Respondents by Gender 
Distribution of Learning Style Frequency. Participants were asked to complete the learning style survey to determine if they were: Active/Reflective, Sensing/Intuitive, Visual/Verbal, or Sequential/Global learners. Each learning style was then characterized by a mild, moderate, or strong preference. There were 10 mild (27.8\%) and three moderate (8.3\%) "Active" learners. Among the 36 respondents there were 15 mild (41.7\%), six moderate (16.7\%), and two strong (5.6\%) "Reflective" learners. There were seven mild (19.4\%) and one strong (2.8\%) "Sensing" learners. Among the students there were 17 mild (47.2\%), 10 moderate (27.8\%), and one strong (2.8\%) "Intuitive" learner. There were four mild (11.1\%) "Visual" learners. There were 13 mild (36.1\%), 13 moderate (36.1\%), and six strong (16.7\%)"Verbal" learners. Within the group there were nine mild (25\%) and three moderate (8.3\%) "Sequential" learners. Within the "Global" category there were 17 (47.2\%) with strong preferences, six (16.7\%) with moderate preference, and one (2.8\%) with a strong "Global" preference (see Table 1).

Distribution of Learning Style Frequency by Gender - Male. The results from the 21 male students were examined to determine the learning styles they preferred. Among the male students there were eight (88.9\%) mild and one (11.1\%) moderate "Active" learners. There were $10(83.3 \%)$ mild and two (16.7\%) moderate "Reflective" learners. There were five (100\%) mild "Sensing" learners. There were 11 (68.8\%) mild and 5 (31.3\%) moderate "Intuitive" male learners. Among the group there were $3(100 \%)$ mild "Visual" learners. Within the group there were eight (44.4\%) mild, seven (38.9\%) moderate, and three (16.7\%) strong "Verbal" learners. There were five (71.4\%) mild and two $(28.6 \%)$ moderate "Sequential" learners. Among the group there were $10(71.4 \%)$ mild and four (28.6\%) moderate "Global" learners (see Table 2). 
Table 1

Distribution of Learning Style Frequency

\begin{tabular}{lcccccc}
\hline & \multicolumn{2}{c}{ Mild } & \multicolumn{2}{c}{ Moderate } & \multicolumn{2}{c}{ Strong } \\
\cline { 2 - 7 } Active & $N$ & $\%$ & $N$ & $\%$ & $N$ & $\%$ \\
Reflective & 10 & 27.8 & 3 & 8.3 & 0 & 0 \\
Sensing & 15 & 41.7 & 6 & 16.7 & 2 & 5.6 \\
Intuitive & 17 & 19.4 & 0 & 0 & 1 & 2.8 \\
Visual & 4 & 47.2 & 10 & 27.8 & 1 & 2.8 \\
Verbal & 13 & 36.1 & 13 & 36.1 & 6 & 0 \\
Sequential & 9 & 25 & 3 & 8.3 & 0 & 0 \\
Global & 17 & 47.2 & 6 & 16.7 & 1 & 2.8 \\
\hline
\end{tabular}

Table 2

Distribution of Learning Style Frequency by Gender - Male

\begin{tabular}{lcccccc}
\hline & \multicolumn{2}{c}{ Mild } & \multicolumn{2}{c}{ Moderate } & \multicolumn{2}{c}{ Strong } \\
\cline { 2 - 6 } & $N$ & $\%$ & $N$ & $\%$ & $N$ & $\%$ \\
\hline Active & 8 & 88.9 & 1 & 11.1 & 0 & 0 \\
Reflective & 10 & 83.3 & 2 & 16.7 & 0 & 0 \\
Sensing & 5 & 100 & 0 & 0 & 0 & 0 \\
Intuitive & 11 & 68.8 & 5 & 31.3 & 0 & 0 \\
Visual & 3 & 100 & 0 & 0 & 0 & 0 \\
Verbal & 8 & 44.4 & 7 & 38.9 & 3 & 16.7 \\
Sequential & 5 & 71.4 & 2 & 28.6 & 0 & 0 \\
Global & 10 & 71.4 & 4 & 28.6 & 0 & 0 \\
\hline
\end{tabular}


Distribution of Learning Style Frequency by Gender - Female. Data from the 15 female students were examined to determine their learning styles. Of the 15 , two $(50 \%)$ were mild and two (50\%) were moderate "Active" learners. Within the group there were five (45.5\%) mild, four (36.4\%) moderate, and two (18.2\%) strong "Reflective" learners. There were two (66.7\%) mild and 1 (33.3\%) strong "Sensing" learners. There were six (50\%) mild, five (41.7\%) moderate, and one (8.3\%) strong "Intuitive" learners. Among the group there was one $(100 \%)$ mild preference "Visual" learner. There were five (35.7\%) mild, six (42.9\%) moderate, and three (21.4\%) strong "Verbal" learners. There were four $(80 \%)$ mild, one $(20 \%)$ moderate "Sequential" Learner. Within the group there were seven mild (70\%), two (20\%), and one (10\%) "Global" learner (see Table 3).

Table 3

Distribution of Learning Style Frequency by Gender - Female

\begin{tabular}{lcccccc}
\hline & \multicolumn{2}{c}{ Mild } & \multicolumn{2}{c}{ Moderate } & \multicolumn{2}{c}{ Strong } \\
\cline { 2 - 7 } & $N$ & $\%$ & $N$ & $\%$ & $N$ & $\%$ \\
\hline Active & 2 & 50 & 2 & 50 & 0 & 0 \\
Reflective & 5 & 45.5 & 4 & 36.4 & 2 & 18.2 \\
Sensing & 2 & 66.7 & 0 & 0 & 1 & 33.3 \\
Intuitive & 6 & 50 & 5 & 41.7 & 1 & 8.3 \\
Visual & 1 & 100 & 0 & 0 & 0 & 0 \\
Verbal & 5 & 35.7 & 6 & 42.9 & 3 & 21.4 \\
Sequential & 4 & 80 & 1 & 20 & 0 & 0 \\
Global & 7 & 70 & 2 & 20 & 1 & 10 \\
\hline
\end{tabular}

Distribution Learning Style Frequency by College - Agriculture. The participants were divided by their respective college. Within the Agriculture College there were nine 
(81.8\%) mild and two (18.2\%) moderate "Active" learners. There were 13 (65\%) mild, five $(25 \%)$ moderate, and two (10\%) strong "Reflective" learners. There were seven (87.5\%) mild and one (12.5\%) strong "Sensing" learner. There were $14(60.9 \%)$ mild, eight (34.8\%) moderate, and one (4.3\%) strong "Intuitive" learner. There were three (100\%) mild "Visual" learners. There were 12 (42.9\%) mild, 12 (42.9\%) moderate, and four (14.3\%) "Verbal" learners. Within the group there were nine mild (81.8\%), and two moderate (18.2\%) "Sequential" learners. Among the Agriculture College there were 14 (70\%) mild, five (25\%) moderate, and one (5\%) strong "Global" learner (see Table 4).

Table 4.

Distribution of Learning Style Frequency by College - Agriculture

\begin{tabular}{lcccccc}
\hline & \multicolumn{2}{c}{ Mild } & \multicolumn{2}{c}{ Moderate } & \multicolumn{2}{c}{ Strong } \\
\cline { 2 - 7 } & $N$ & $\%$ & $N$ & $\%$ & $N$ & $\%$ \\
\hline Active & 1 & 50 & 1 & 50 & 0 & 0 \\
Reflective & 2 & 66.7 & 1 & 33.3 & 0 & 0 \\
Sensing & 0 & 0 & 0 & 0 & 0 & 0 \\
Intuitive & 3 & 60 & 2 & 40 & 0 & 0 \\
Visual & 1 & 100 & 0 & 0 & 0 & 0 \\
Verbal & 1 & 25 & 1 & 25 & 2 & 50 \\
Sequential & 0 & 0 & 1 & 100 & 0 & 0 \\
Global & 3 & 75 & 1 & 25 & 0 & 0 \\
\hline
\end{tabular}

Distribution of Learning Style Frequency by College - Forestry. Within the Forestry College there were five respondents. Among this group there was one (50\%) mild "Active" learner and one (50\%) moderate "Active" learner. There were two (66.7\%) mild, and one (33.3\%) moderate "Reflective" learner. Among this group no one had a 
preference as a "Sensing" learner. There were three $(60 \%)$ mild, and two $(40 \%)$ moderate "Intuitive" learners. There was one (100\%) "Visual" learner. Within the group there was one (25\%) mild, one (25\%) moderate, and two (50\%) strong "Verbal" learners. There was one $(100 \%)$ respondent that showed a moderate preference for "Sequential" learning. There were three (75\%) mild and one (25\%) moderate "Global" learners among the group from the Forestry College (see Table 5).

Table 5

Distribution of Learning Style Frequency by College - Forestry

\begin{tabular}{lcccccc}
\hline & \multicolumn{2}{c}{ Mild } & \multicolumn{2}{c}{ Moderate } & \multicolumn{2}{c}{ Strong } \\
\cline { 2 - 7 } & $N$ & $\%$ & $N$ & $\%$ & $N$ & $\%$ \\
\hline Active & 9 & 81.8 & 2 & 18.2 & 0 & 0 \\
Reflective & 13 & 65 & 5 & 25 & 2 & 10 \\
Sensing & 7 & 87.5 & 0 & 0 & 1 & 12.5 \\
Intuitive & 14 & 60.9 & 8 & 34.8 & 1 & 4.3 \\
Visual & 3 & 100 & 0 & 0 & 0 & 0 \\
Verbal & 12 & 42.9 & 12 & 42.9 & 4 & 14.3 \\
Sequential & 9 & 81.8 & 2 & 18.2 & 0 & 0 \\
Global & 14 & 70 & 5 & 25 & 1 & 5 \\
\hline
\end{tabular}

Phase II

Distribution of Teaching Style Frequency by Teachers. The teaching styles of the teachers at ECIAF were analyzed. The types of teaching styles were characterized by: 
Active, Reflective, Sensing, Intuitive, Visual, Verbal, Sequential, and Global (see Table $6)$.

One hundred percent of the teachers at ECIAF demonstrated using an "Active" teaching style. Examples of this teaching styles included: students solving problems in groups, producing crops in lab setting, and group discussion. Eighty percent of the teachers demonstrated the "Reflective" method. Examples of this teaching method included: asking students to talk about past lecture topics, discussion of past lab crop experiences, and discussion of reading topics with time given for reading in class. Two $(40 \%)$ of the teachers demonstrated "Sensing" teaching techniques. Examples of this teaching style included: visiting a vegetable packing plant, and giving examples of how different regional crops are used in production. One (20\%) teacher demonstrated the "Intuitive" teaching technique by giving theories of experimental designs in the topic of statistics. Eighty percent of the teachers used "Visual" teaching styles. Examples of this teaching style included: using the chalkboard and overheads to display diagrams and charts, bringing in pieces of plants, seeds, and forages, and giving handouts to students. Five $(100 \%)$ of the teachers displayed a "Verbal" teaching style. Examples of this teaching style included: lecture, and handouts. Three (60\%) of the teachers demonstrated "Sequential" teaching styles. Examples of this teaching style included: care of crop instructions, examples of math equations, discussion of international markets, and the discussion of planting crops. Five (100\%) of the teachers demonstrated "Global" teaching methods. Examples of this were primarily done by giving an overview of the topic before class to depict what the class is going to cover (see Table 6). 
Table 6

Distribution of Teaching Style Frequency by Teachers

\begin{tabular}{lcc}
\hline & Number of Teachers & Percent \\
\hline Active & 5 & $100 \%$ \\
Reflective & 4 & $80 \%$ \\
Sensing & 2 & $40 \%$ \\
Intuitive & 1 & $20 \%$ \\
Visual & 4 & $80 \%$ \\
Verbal & 5 & $100 \%$ \\
Sequential & 3 & $60 \%$ \\
Global & 5 & $100 \%$ \\
\hline
\end{tabular}




\section{CHAPTER V}

Conclusions, Implications, and Recommendations

\section{Purpose of the Study}

The purpose of the study was to determine the learning styles of first-year students at Eastern Caribbean Institute of Agriculture and Forestry (ECIAF) and to determine the teaching strategies faculty used to match instruction with student learning styles.

\section{Objective}

The objective of the study was to determine if the teachers at ECIAF are using instructional methods that facilitate learning in their students. The current first-year students at ECIAF were assessed and taught about their learning styles so that they can understand how they learn. In addition, instructors at ECIAF were observed to determine the degree to which they utilize teaching methods that take into consideration the learning styles of their students. After the assessment of the students, the teachers were given the opportunity to see the statistics so they could see if their instructional methods coincide with their students learning styles.

\section{Research Questions}

The following research questions were used to guide the research:

1. What are the predominate learning styles of the first-year students at the Institute?

2. What instructional methods do instructors utilize at the Institute?

3. To what extent do learning styles of students and teaching methods of instructors coincide? 


\section{Conclusions}

Phase I. A majority of the students were "Reflective" learners. This represented $63 \%$ of the population. Reflective learners like to have time to think about what is being said to them, they also do not like lectures because it is hard to take in information without having time too reflect. Reflective learners like to work alone or in pairs.

An overwhelming majority of the students were "Intuitive" learners. This was $77 \%$ of the population. Intuitive learners are very imaginative and like information that comes from their imagination. They enjoy reflection but maybe careless when it comes to detailed work.

An overwhelming majority of the students had "Verbal" preferences of learning. This was $89 \%$ of the population. Verbal learners learn better by written words, and words in a lecture style format. Sometimes when verbal learners do not hear the information being introduced to them it is hard for the student to understand the information.

A majority of the students had a "Global" learning preference. This was $67 \%$ of the population. Global learners take in information in unconnected fragments and achieve understanding in big leaps. Global learners often do poorly on homework and do not work very fast but once they understand the topic everything starts to fit in.

Phase II. All five teachers demonstrated an "Active" teaching style. By using an "Active" teaching method this allowed students to talk, move, and reflect during the course of the class period.

There were four teachers who demonstrated a "Reflective" or passive teaching method. This method allowed students to watch and listen as the instructor presents information. 
There were four teachers who demonstrated a "Visual" teaching style. By using this method the instructors included pictures, diagrams, film, or demonstrations to help the students understand the information being presented within the class.

All of the teachers used a "Verbal" teaching style. By using a verbal teaching method this meant that the instructor included lecture, readings, and discussions within their classroom.

All of the teachers taught with a "Global" teaching style. By using this method in the classroom it allowed students to be introduced to a topic by including the context of the topic and the relevance.

\section{Implications \& Recommendations}

1. An implication of this study is that the teachers do teach to the majority of the learning styles of the students. Among these are reflective, verbal, and global learning styles. It is recommended that the teachers at ECIAF implement a learning style assessment within their classrooms to help structure their lesson plans around their students.

2. An implication of this study is that an overwhelming majority of the students are "Intuitive" learners, while only $20 \%$ of the teachers teach with an "Intuitive" teaching style. It is recommended that the teachers of ECIAF research how to improve their intuitive teaching style and incorporate this into their classroom to be able to reach these students.

3. It is recommended that a longitudinal study at ECIAF be conducted to test for differences in statistics. 
4. It is recommended that replications of this study be done with a larger number of students and teachers.

5. It is recommended that the teachers should make a point to increase their knowledge of learning styles research to improve learning in the classroom and also to improve their teaching techniques.

6. It is recommended that a study be conducted to see if culture makes a difference in learning styles of the students at ECIAF compared to the students at West Virginia University. 


\section{REFERENCES}

Ary, D., Jacobs, L. C., and Razavieh, A. (2002). Introduction to research in education. Belmont, CA : Wadsworth/Thomson Learning.

Chapman, P., Hart, L., Hicks, R., Lawrence, L., Medley, F., Wells, J. (2003, February). College of science, Technology and Applied Arts of Trinidad and Tobago, Final Report of the External Consultants. Morgantown, West Virginia.

Cornett, C. (1983). What you should know about teaching and learning styles. Bloomington, Ind.: Phi Delta Kappa Educational Foundation. (ERIC Document ED 228 235)

Claxton, C. S., and Murrell, P.S. (1987). Learning styles: Implications for improving Educational Practices. (Report No. 4) Washington, D.C.: ERIC Clearinghouse on Higher Education. (ERIC Document ED 293 478)

Debello, T. (1989). Comparison of eleven major learning styles models: variables; appropriate populations; validity of instrumentation; and the research behind them. (ERIC Document ED 312 093)

Dunn, K., and Dunn, R., and Price, G.E. (1977). Productivity environmental survey.

Felder, R. (1993). Reaching the second tier: learning and teaching styles in college science education. [Electronic version]. J. College Science Teaching, 23(5) 268290 http://www.ncsu.edu/felder-public/Papers/Secondtier.html

Felder, R. M. (1996). Matters of style. [Electronic version]. ASEE Prism, 6(4), 18-23. Retrieved April 16, 2003, from http:// www.ncsu.edu/felder-public/papers/LSPrism.htm

Felder, R. M. (1988). Learning and teaching styles in engineering education. [Electronic version]. Engr. Education, 78(7), 674-681. Retrieved April 16, 2003, from http:// www.ncsu.edu/felder-public/papers/LS-Prism.htm

Felder, R, M. \& Soloman B. A., (1991). Index of learning styles. Retrieved March 23 from http://www.ncsu.edu/felder-public/ILSpage.html

Green, K. E. (1985). Cognitive style: A review of literature. (ERIC Document ED 289 902)

Griggs, S. A., and Price, G. E. (1985). Counseling college students through their individual learning styles. Ann Arbor, MI: ERIC Clearinghouse on Counseling and Personnel Services. (ERIC Document Reproduction Services No. ED 265 455) 
Griggs, S. A. (1991). Learning styles counseling. Ann Arbor, MI: ERIC Counseling and Personnel Services Clearinghouse

Haring, E. (1985). Teaching and learning styles. (ERIC Document ED 258 658)

Keefe, J. W. (1987). Learning style theory and practice. (ERIC Document ED 286873 )

Kirby, P. (1979). Cognitive style, learning style, and transfer skill acquisition. Information Series No. 195. Columbus, OH: Ohio State University, National Center for Research in Vocational Education

Knowles, M. S., and Associates (1984). Andragogy in action: Applying modern principles to adult learning. San Francisco, CA: Jossey-Bass.

Matthews, D. (1995). An investigation of the learning styles of students at selected postsecondary and secondary institutions in South Carolina. (Research Bulletin No. 60) Orangeburg, S.C. : Department of Agriculture. (ERIC Document ED 386 098)

Ramirez, M. (1982). Cognitive styles and cultural diversity. Paper presented at the annual meeting of the American Educational Research Association, New York, N.Y.

Serasin, L. C. (1999). Learning style perspectives: impact in the classroom. Madison, WI: Atwood Publishing.

Sheal, P. B. (1989). How to develop and present staff training courses. London: Kogen Page.

Sims, R. R. and Sims J. S. (1995). The importance of learning styles: Understanding the implications for learning, course design, and education. Westport, CT: Greenwood Press.

Swanson, L. J. (1995). Learning styles: A review of the literature. (ERIC Document ED 387 067).

Walls R. T. (1999). Psychological foundations of learning. West Virginia University, Morgantown, WV: Library of Congress Cataloging in Publication Data.

Zywno, M. S. (2003). A contribution to validation of score meaning for FelderSoloman's index of learning styles. [Electronic Version] Proceedings of the 2003 American Society for Engineering Education Annual Conference and Exposition, American Society for Engineering Education 
APPENDICES 
APPENDIX A

Index of Learning Styles by Felder \& Soloman (1991) 


\title{
INDEX OF LEARNING STYLES
}

\author{
Barbara A. Soloman \\ Richard M. Felder \\ North Carolina State University \\ Raleigh, NC 27695-7905
}

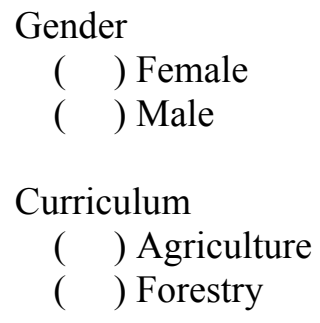

\section{DIRECTIONS}

Circle "a" or "b" to indicate your answer to every question. Please choose only one answer for each question. If both "a" and "b" seem to apply to you, choose the one that applies more frequently.

1. I understand something better after I

(a) try it out.

(b) think it through.

2. I would rather be considered

(a) realistic.

(b) innovative.

3. When I think about what I did yesterday, I am most likely to get

(a) a picture.

(b) words.

4. I tend to

(a) understand details of a subject but may be fuzzy about its overall structure.

(b) understand the overall structure but may be fuzzy about details.

5. When I am learning something new, it helps me to

(a) talk about it.

(b) think about it.

6. If I were a teacher, I would rather teach a course

(a) that deals with facts and real life situations.

(b) that deals with ideas and theories.

7. I prefer to get new information in

(a) pictures, diagrams, graphs, or maps.

(b) written directions or verbal information.

8. Once I understand

(a) all the parts, I understand the whole thing.

(b) the whole thing, I see how the parts fit.

9. In a study group working on difficult material, I am more likely to

(a) jump in and contribute ideas. 
(b) sit back and listen.

10. I find it easier

(a) to learn facts.

(b) to learn concepts.

11. In a book with lots of pictures and charts, I am likely to

(a) look over the pictures and charts carefully.

(b) focus on the written text.

12. When I solve math problems

(a) I usually work my way to the solutions one step at a time.

(b) I often just see the solutions but then have to struggle to figure out the steps to get to them.

13. In classes I have taken

(a) I have usually gotten to know many of the students.

(b) I have rarely gotten to know many of the students.

14. In reading nonfiction, I prefer

(a) something that teaches me new facts or tells me how to do something.

(b) something that gives me new ideas to think about.

15. I like teachers

(a) who put a lot of diagrams on the board.

(b) who spend a lot of time explaining.

16. When I'm analyzing a story or a novel

(a) I think of the incidents and try to put them together to figure out the themes.

(b) I just know what the themes are when I finish reading and then I have to go back and find the incidents that demonstrate them.

17. When I start a homework problem, I am more likely to

(a) start working on the solution immediately.

(b) try to fully understand the problem first.

18. I prefer the idea of

(a) certainty.

(b) theory.

19. I remember best

(a) what I see.

(b) what I hear.

20. It is more important to me that an instructor

(a) lay out the material in clear sequential steps.

(b) give me an overall picture and relate the material to other subjects.

21. I prefer to study

(a) in a study group.

(b) alone.

22. I am more likely to be considered

(a) careful about the details of my work.

(b) creative about how to do my work.

23. When I get directions to a new place, I prefer

(a) a map.

24. I learn

(b) written instructions.

(a) at a fairly regular pace. If I study hard, I'll "get it."

(b) in fits and starts. I'll be totally confused and then suddenly it all "clicks."

25. I would rather first

(a) try things out.

(b) think about how I'm going to do it. 
26. When I am reading for enjoyment, I like writers to

(a) clearly say what they mean.

(b) say things in creative, interesting ways.

27. When I see a diagram or sketch in class, I am most likely to remember

(a) the picture.

(b) what the instructor said about it.

28. When considering a body of information, I am more likely to

(a) focus on details and miss the big picture.

(b) try to understand the big picture before getting into the details.

29. I more easily remember

(a) something I have done.

(b) something I have thought a lot about.

30. When I have to perform a task, I prefer to

(a) master one way of doing it.

(b) come up with new ways of doing it.

31. When someone is showing me data, I prefer

(a) charts or graphs.

(b) text summarizing the results.

32. When writing a paper, I am more likely to

(a) work on (think about or write) the beginning of the paper and progress forward.

(b) work on (think about or write) different parts of the paper and then order them.

33. When I have to work on a group project, I first want to

(a) have "group brainstorming" where everyone contributes ideas.

(b) brainstorm individually and then come together as a group to compare ideas.

34. I consider it higher praise to call someone

(a) sensible.

(b) imaginative.

35. When I meet people at a party, I am more likely to remember

(a) what they looked like.

(b) what they said about themselves.

36. When I am learning a new subject, I prefer to

(a) stay focused on that subject, learning as much about it as I can.

(b) try to make connections between that subject and related subjects.

37. I am more likely to be considered

(a) outgoing.

(b) reserved.

38. I prefer courses that emphasize

(a) concrete material (facts, dat(a).

(b) abstract material (concepts, theories)

39. For entertainment, I would rather

(a) watch television.

(b) read a book.

40. Some teachers start their lectures with an outline of what they will cover. Such outlines are

(a) somewhat helpful to me.

(b) very helpful to me.

41. The idea of doing homework in groups, with one grade for the entire group,

(a) appeals to me.

(b) does not appeal to me.

42. When I am doing long calculations,

(a) I tend to repeat all my steps and check my work carefully.

(b) I find checking my work tiresome and have to force myself to do it. 
43. I tend to picture places I have been

(a) easily and fairly accurately.

(b) with difficulty and without much detail.

44. When solving problems in a group, I would be more likely to

(a) think of the steps in the solution process.

(b) think of possible consequences or applications of the solution in a wide range of areas.

When you have finished, please record your responses on the attached Scoring Sheet. 
APPENDIX B

ILS Scoring Sheet 


\section{ILS SCORING SHEET}

1. Put "1"s in the appropriate spaces in the table below (e.g. if you answered "a" to Question 3, put a "1" in Column A by Question 3).

2. Total the columns and write the totals in the indicated spaces.

3. For each of the four scales, subtract the smaller total from the larger one. Write the difference (1 to 11) and the letter (a or b) for which the total was larger on the bottom line.

For example, if under "ACT/REF" you had 4 "a" and 7 "b" responses, you would write " $3 \mathrm{~b}$ " on the bottom line under that heading $(3=7-4$, and the " $b$ " total was the larger of the two)

\begin{tabular}{|c|c|c|c|}
\hline ACT/REF & SNS/INT & VIS/VRB & SEQ/GLO \\
\hline $\mathrm{Q} a \mathrm{~b}$ & $\mathrm{Q} a \mathrm{~b}$ & Q a b & $\mathrm{Q} a \mathrm{~b}$ \\
\hline$-\ldots$ & 2 & 3 & 4 \\
\hline 5 & 6 & 7 & 8 \\
\hline 9 & 10 & 11 & 12 \\
\hline 13 & 14 & 15 & 16 \\
\hline 17 & 18 & 19 & 20 \\
\hline 21 & 22 & 23 & 24 \\
\hline 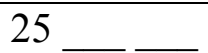 & 26 & 27 & 28 \\
\hline - & - & - _ & 32 \\
\hline 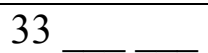 & 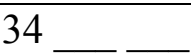 & 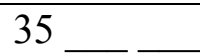 & -1 \\
\hline- & 38 & 39 & 40 \\
\hline - & 42 & 43 & 44 \\
\hline \multicolumn{4}{|c|}{ Total (sum X's in each column) } \\
\hline ACT/REF & SNS/INT & VIS/VRB & SEQ/GLO \\
\hline $\mathrm{a} / \mathrm{b}$ & $\mathrm{a} / \mathrm{b}$ & $\mathrm{a} / \mathrm{b}$ & $\mathrm{a} / \mathrm{b}$ \\
\hline - - & - & - & - - \\
\hline \multicolumn{4}{|c|}{ (Larger - Smaller) + Letter of Larger (see below*) } \\
\hline 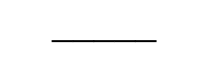 & _ & - & - \\
\hline
\end{tabular}

*Example: If you totaled 3 for a and 8 for $b$, you would enter $5 \mathrm{~b}$ in the space below.

Explanation of scores:

*If your score on a scale is $1-3$, you are fairly well balanced on the two dimensions of that scale.

*If your score on a scale is 5 or 7 , you have a moderate preference for one dimension of the scale and will learn more easily in a teaching environment, which favors that dimension.

* If your score on a scale is 9 or 11 , you have a very strong preference for one dimension of the scale. You may have real difficulty learning in an environment, which does not support that preference. 
APPENDIX C

Teaching Style Checklist 


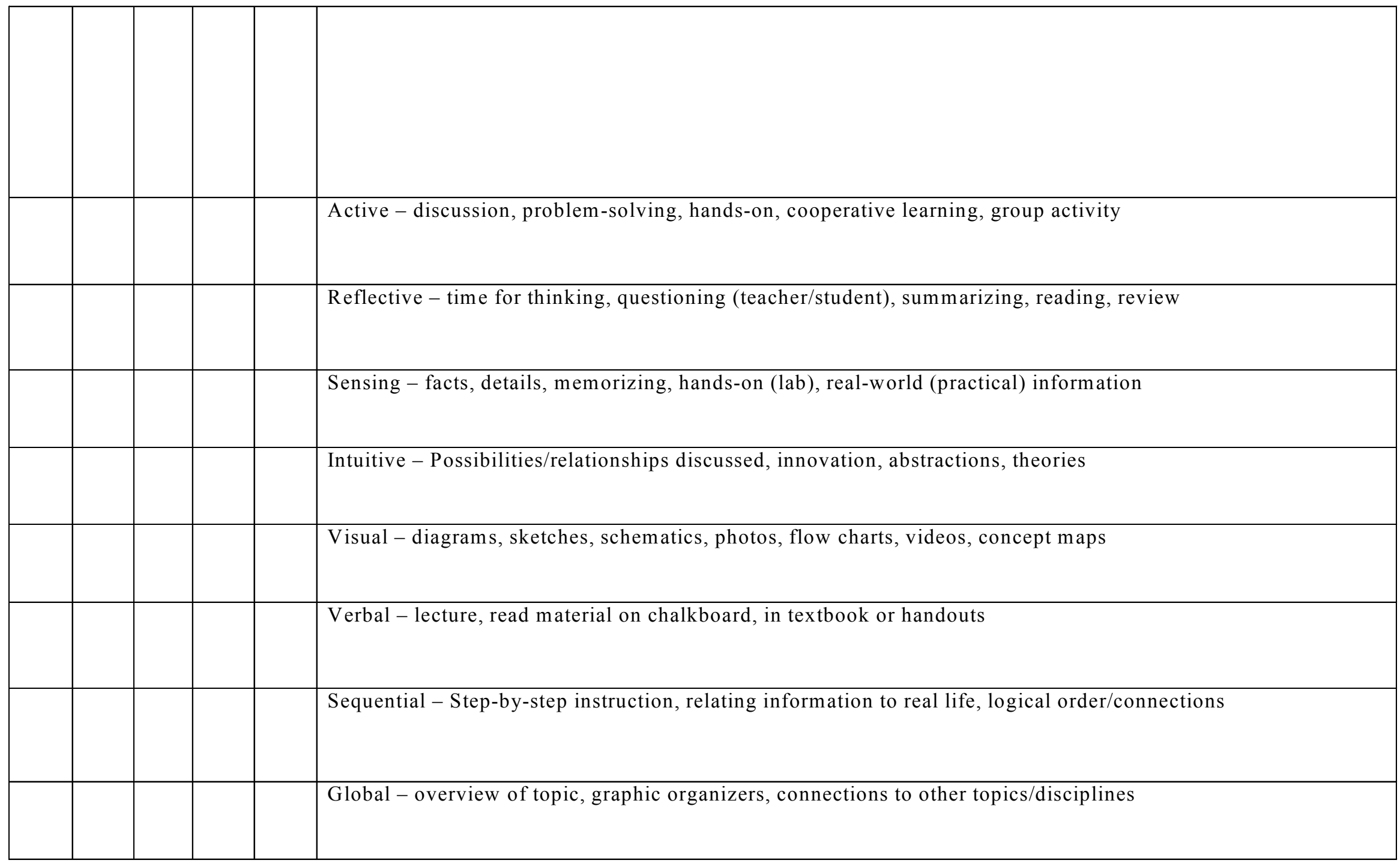




\section{APPENDIX D}

Letter of Introduction \& Survey Directions 


\section{Introductory Remarks}

My name is Cindy Burskey and I am currently pursuing a Master of Science degree in Agriculture Education at West Virginia University. In partial fulfillment of my degree requirements I am conducting research assessing the Learning Styles of the first year students at the Eastern Caribbean Institute of Agriculture and Forestry in Trinidad.

By gaining knowledge of learning styles you as the student should be able to more productively learn in the classroom environment and also on your own. The learning style theory implies that how much individuals learn has more to do with whether the educational experience is geared toward the students particular style of learning.

I have a 44-question learning styles quiz that I would like for you to take. This test will only take about 10 minutes of your time and participation is voluntary. Please note that you do not have to answer every question, and your answers will be kept as confidential as possible.

Your participation in this research study will help the education program at the Eastern Caribbean Institute of Agriculture and Forestry in Trinidad. 
May 6, 2003

Dear

Learning styles is important in teaching. Learning to accommodate different learning styles has become more important to me in the past year because of my enrollment in graduate school in the Agricultural Education Program. With my emphasis being in extension, my public teaching ability should improve in order to reach all different audiences. Incorporating different teaching methods in my presentations will make it easier to reach all of the learning styles in the class. In my search for a thesis topic I felt that it would be appropriate to address learning styles.

One of my educational goals at West Virginia is to incorporate an international emphasis into my class structure. Upon hearing this, my thesis committee approached me and asked if I would be interested in going to the Eastern Caribbean Institute of Agriculture and Forestry, Centeno, Trinidad and Tobago (ECIAF). I felt that it would be appropriate to assess the learning styles of all first year students and to identify the teaching methods used by the teachers of ECIAF. My research will determine if the teaching methods of the teachers of ECIAF match the learning styles of the students. The results of the study will be used to prepare a thesis to partially fulfill the requirements for a Master of Science Degree in Agricultural Education.

Participation in this research study, while voluntary, will only take about 10 minutes of your time. You may skip any question you are not comfortable answering. Please be assured the all information will be held as confidential as possible and that refusal to participate in the study will not affect the subject's grade in any. Survey results will be reported in a summary format and individual responses will not be identifiable.

Thank you for your time in participating in this study.

Sincerely,

Cynthia M. Burskey

Graduate Student
Harry N. Boone

Assistant Professor 
APPENDIX E

Research Funding Proposal 
Assessment of the Learning Styles of Students at the Eastern Caribbean Institute of Agriculture and Forestry, Centeno, Trinidad and Tobago and Identification of Teaching Methods Used by Instructors to Meet the Learning Style Needs of the Students

\section{Person Involved:}

Cynthia M. Burskey - Graduate Student, Agricultural and Environmental Education, West Virginia University

\section{Research Activity:}

The research activity involves the assessment of the learning styles of students at the Eastern Caribbean Institute of Agriculture and Forestry, Centeno, Trinidad and Tobago (ECIAF). In addition instructors at ECIAF will be observed to determine the degree they utilize teaching methods that take into consideration the learning styles of their students.

Descriptive research methodology will be utilized in the research study. The population for phase I will consist of all 50 first-year students at the Institute. The population for phase II will consist of selected instructors at the Institute.

Research Questions: The following research questions will be used to guide the research:

1. What are the predominate learning style of the first-year students at the Institute?

2. What instructional methods are used by instructors at the Institute?

3. To what extent do learning styles of students and teaching methods of instructors coincide?

Methodology: Each student's learning style will be assessed using a learning styles inventory (presently seeking permission of copyright owners). This inventory determines whether the student is an auditory, visual or kinesthetic learner. The students will be informed of their results and learn what each type of learning style means.

Teaching methods used by instructors will be assessed by observation while shadowing two to three students through their day's schedules. Methodologies will be determined in each class by using a five-minute timed interval and recording the teaching method(s) used during that time period.

\section{History}

Columbus explored the island of Trinidad, which lies just off Venezuela, in 1498. Over the centuries, it was claimed by the Spanish, passed between the British and French several times and finally remained with the British in 1802. Trinidad and Tobago, a smaller island a few miles to the northeast, were granted independence from the British in 1962 but remain with the British Commonwealth. The two islands are about a tenth the area of West Virginia. Population of 1.2 million is composed of about half who are descended from African slaves, the other half from descendents of indentured workers from India, brought to the islands to work the sugarcane plantations. Although several languages are spoken, English is the official language. 
The British established ECIAF in 1954. The institute, which is a boarding school, sits on 230 acres of land. Twenty-five agriculture and 25 forestry students are admitted annually, thus up to 100 students may be on campus each year. Following a two-year curriculum, a diploma is issued to students. There are 10 faculty members and three "technical assistants." There are also some 150 staff members who prepare meals, do secretarial work, and work in the livestock and crops area.

\section{Experience \& Qualifications:}

I have prepared myself for this international experience by traveling and reading about different places and cultures throughout my education. One of my excursions was to Swaziland. I studied and traveled in and around the area including South Africa, Mozambique, and Zimbabwe. I stayed at the University of Swaziland in a dorm building and hung out with the students. In class I studied the education, government, wildlife and the wonderful culture. On my trips outside the university I visited farms, schools (primary and secondary), and different organizations such as UNICEF. I feel this experience will be similar to what I will find in Trinidad and am excited to see what the differences are.

My long-term education goals are to attain my master's degree in agricultural education and become an extension agent within a county. Eventually, I would like to become involved with extension on an international level and work oversees. This experience will help me attain my master's degree and also help me gain more experience being in another culture and perhaps pave the way for an international career later in life.

\section{Benefits:}

The Davis College of Agriculture, Forestry and Consumer Sciences at West Virginia University and the College of Science, Technology and Applied Arts of Trinidad and Tobago (COSTAATT) are building a cooperative relationship. COSTAATT's agriculture and forestry branch is ECIAF, a two-year school that offers an associate degree in Agriculture and Forestry. COSTAATT wants to upgrade their student experiences and classes and would like to be able to give their students the option of transferring their credits to WVU or vice versa.

This past winter break a group of six faculty members from WVU were given the opportunity to visit COSTAATT. These six faculty members explored the idea of becoming "sister universities" with COSTAATT. My research project will be the first of many to try to build this relationship. The chair of Agricultural and Environmental Education, Dr. Layle Lawrence, and other AGEE faculty have approved my research proposal. Mr. Carlton Sanbury, Director of ECIAF, has approved the project as well and has offered lodging and accommodations at the institute.

This visit to ECIAF will begin to bridge the relationship between West Virginia University and COSTATT. My research will help by identifying whether the teaching styles of the professors match the learning styles of the students. The research will be 
useful in a teaching method and materials workshop to be offered during July at ECIAF by AGEE faculty.

Upon completion of my research, I plan to complete my thesis and present my findings to my committee and to the faculty members who are helping in bridging this relationship with Trinidad. I also hope to publish my paper in the Journal of International Agricultural and Extension Education and present the findings at the annual conference of the Association of International Agricultural and Extension Education.

\section{Itemized Budget:}

Hotel: (approx 3 nights) $\$ 360$

Meals: $\quad \$ 120$

Taxi: $\quad \$ 100$

Airfare: $\quad \$ 1250$

Total ------------------------ $\$ 1830$

*ECIAF will be providing housing and meals for 6 days and 5 nights.

\section{Quotes from National Travel:}

Travel Dates: From: May $17^{\text {th }}$ To: May $25^{\text {th }}$

Amount: \$1250-\$1326 
VITA

Cynthia M. Burskey

3579 Schrack Rd.

Lucas, Ohio 44843

August 3, 1979

Born: Kingsport, Tennessee

June, 1997

Graduated - Lucas High School Lucas, Ohio

June, 1999

Associate of Science

Horticulture

The Ohio State University

Agricultural Technical Institute

Wooster, Ohio

June, 2001

Bachelor of Science

Agricultural Communications

The Ohio State University

Columbus, Ohio

May, 2004

Master of Science

Agricultural and Environmental

Education

West Virginia University

Morgantown, West Virginia 